\title{
Effects of Antrodia Camphorata Supplementation on Anti-fatigue Effects in Rats 補充樟芝對老鼠抗痩勞作用的影響
}

\author{
Chieh-Chung LIU ${ }^{1}$ Chun-Hong LIN ${ }^{1}$ City C. HSIEH ${ }^{2}$ \\ Wu-Che WEN $^{3}$ Mao-Tien KUO ${ }^{3}$ Pu-Hsi TSAI ${ }^{1}$ \\ ${ }^{I}$ Department of Physical Education, Yuanpei University, \\ Hsin Chu, TAIWAN \\ ${ }^{2}$ Department of Physical Education, \\ National HsinChu University of Education, Hsin Chu, TAIWAN \\ ${ }^{3}$ Golden Biotechnology Corporation, Taipei, TAIWAN
}

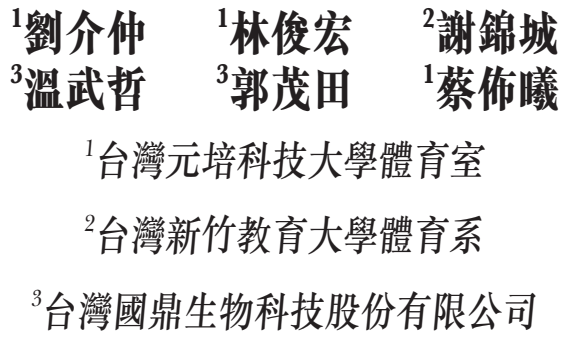

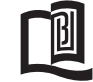

\begin{abstract}
This study investigated the effects of antrodia camphorata (AC) supplementation on anti-fatigue effects after a single bout of exhaustive exercise in rats. Thirty-two rats were randomly divided into four groups: control $(\mathrm{C}, \mathrm{n}=8)$; $\mathrm{C}$ with antrodia camphorata supplementation $(A, n=8)$; exhaustive exercise $(E, n=8)$; exhaustive exercise with $A C$ supplementation $(\mathrm{AE}, \mathrm{n}=8)$. Rats in groups $\mathrm{A}$ and $\mathrm{AE}$ received a 0.2 c.c. $(\mathrm{kg} / \mathrm{wt} / \mathrm{day}) \mathrm{AC}$ supplementation for two weeks. Rats in groups $\mathrm{E}$ and $\mathrm{AE}$ performed an exhaustive running test on a treadmill at a final speed of $30 \mathrm{~m} / \mathrm{min}, 10 \%$ grade, at approximately 70 $75 \% \mathrm{VO}_{2} \max$. Blood samples of each rat were collected. The concentrations of glucose, lactate dehydrogenase (LDH), uric acid, creatinine, and creatine kinase (CK) in blood were examined. The results showed a significant increase in exhaustive exercise time of $\mathrm{AE}$ group $(78.79 \pm 9.09 \mathrm{~min})$ compared with $\mathrm{E}$ group $(67.77 \pm 9.22 \mathrm{~min})$. The activities of $\mathrm{CK}$, LDH, and blood creatinine concentration significantly increased in exercised rats $(1227.40 \pm 553.24 \mathrm{U} / \mathrm{I}, 2108.32 \pm 513.99 \mathrm{U} / \mathrm{I}, 0.76 \pm 0.19 \mathrm{mg} /$ dl) compared with control group rats $(358.98 \pm 125.53 \mathrm{U} / \mathrm{I}, 956.89 \pm 597.13 \mathrm{U} / \mathrm{I}, 0.5 \pm 0.15 \mathrm{mg} / \mathrm{dl})$ and AE group rats $(774.13 \pm 203.38$ U/I, $1300.93 \pm 513.99 \mathrm{U} / \mathrm{I}, 0.5 \pm 0.05 \mathrm{mg} / \mathrm{dl})$. The glucose in the plasma significantly decreased in E group rats (133.88 \pm 61.84 $\mathrm{mg} / \mathrm{dl})$ compared with $\mathrm{C}$ group rats $(209.63 \pm 69.13 \mathrm{mg} / \mathrm{dl})$ and $\mathrm{AE}$ group rats $(188.88 \pm 60.32 \mathrm{mg} / \mathrm{dl})$. The results indicate that AC supplementation could decrease CK, LDH activities. It may help for anti-fatigue effects.
\end{abstract}

Key words: antrodia camphorata, exercise

\section{摘 要}

本研究的目的在探討, 樟芝補充劑對老鼠經單次衰竭運動後對抗疲勞作用的影響, 三十二隻老鼠隨機分配為以下四組：控制 組 $(\mathrm{C}, \mathrm{n}=8)$ ) 樟芝組 $(A, \mathrm{n}=8$, 補充樟芝, 沒有運動) 、運動組 $(\mathrm{E}, \mathrm{n}=8)$ 、樟芝運動組 $(\mathrm{AE}, \mathrm{n}=8$, 補充樟芝, 有運動), 補充樟芝組 (A \& AE)的老鼠, 每天補充每公斤體重 0.2 毫升的樟芝補充劑, 持續兩週, 衰竭運動組 $(\mathrm{E} \& \mathrm{AE}$ ) 的老鼠需在鼠用跑步機上進行 衰竭運動, 運動強度約70 75\%最大攝氧量, 最終跑步機速度為30公尺/分鐘, 坡度為 $10 \%$ 。收集老鼠血液樣本, 測量血糖、乳酸 
去氫酶、尿酸、肌酸酐、肌酸激酶。研究結果顯示AE組運動衰竭時間(78.79 $\pm 9.09 \quad \mathrm{~min})$ 顯著比E組 $(67.77 \pm 9.22 \mathrm{~min})$ 長。運動組

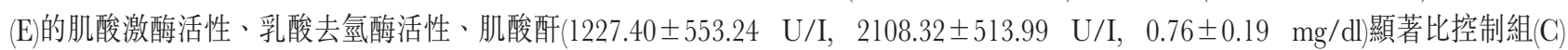
(358.98 $\pm 125.53 \mathrm{U} / \mathrm{I} ， 956.89 \pm 597.13 \mathrm{U} / \mathrm{I} ， 0.5 \pm 0.15 \mathrm{mg} / \mathrm{dl})$ 及樟芝運動組(AE)高(774.13 $\pm 203.38 \mathrm{U} / \mathrm{I}, \quad 1300.93 \pm 513.99 \mathrm{U} /$ I， $0.5 \pm 0.05 \mathrm{mg} / \mathrm{dl})$ 。運動組(E)血糖濃度(133.88 $\pm 61.84 \mathrm{mg} / \mathrm{d})$ 顯著比控制組 $(209.63 \pm 69.13 \mathrm{mg} / \mathrm{dl}$ )及樟芝運動組 $(188.88 \pm 60.32$ $\mathrm{mg} / \mathrm{dl}$ )低。研究結果表示樟芝補充能夠降低肌酸激酶活性及乳酸去氫酶活性, 有助於抗疲勞的效用。

關鍵字：樟芝，運動

\section{Introduction}

Antrodia camphorata is a parasitic fungus on the inner heartwood wall of rotted trees of the endangered Cinnamum kanehirai Hay (Lauraceae) in Taiwan (Wu et al., 1997). As a folk remedy, its fruiting body has long been used for food and drug intoxication, and the treatment of diarrhea, abdominal pain, hypertension, itching of the skin, and liver cancer (Chen et al., 2006). However, due to its slow growth rate in nature and since it cannot be mass produced in the greenhouse thus far, the fruiting bodies are very rare and expensive. In order to search for materials which would substitute for the fruiting bodies collected in nature, the cultured mycelium of A. camphorate has been found to exhibit anti-inflammatory activity (Shen et al., 2004), vasorelaxation (Wang et al., 2003), cytotoxic activity against several tumor cell lines (Liu et al., 2004), protection of oxidative damage in normal human erythrocytes (Hseu et al., 2002), and anti-hepatitis B virus activity (Lee et al., 2002) in biological studies.

Adequate dietary supplements or nutritional ergogenic aids are an important means to optimize exercise performance and to ward off fatigue. Ergogenic aids are believed to increase performance by some of the following mechanisms: renewing or increasing energy stores in the body, facilitating the biochemical reactions that yield energy, reducing or neutralizing performanceinhibiting metabolic byproducts, and facilitating recovery (Lawrence \& Kirby, 2002; Maughan et al., 2004). Performance in aerobic-type events depends on the ability to maintain a high output per unit of time. There is a growing inclination among athletes to use herbs to improve endurance performance or increase recovery after exercise.

There is relatively little research that shows a performance benefit of AC in human beings. The purpose of the present study was to determine, whether 2 wk of oral supplementation with AC had any benefit on exhaustive exercise.

\section{Methods}

\section{Animals}

Thirty-two male Sprague-Dawley rats weighting 280$300 \mathrm{~g}$ (8 weeks old) were purched from the National Laboratory Animal Breeding and Research Center (Taipei Taiwan). All rats were given Purina 5001 powder chow (Rodent Laboratory Chow 5001; Purina, St Louis, MO, USA) and tap water ad libitum and housed in a room maintained at $23 \pm 2^{\circ} \mathrm{C}$ with a $12 \mathrm{~h}$ light-dark cycle. Rats were randomly divided into four groups: a sedentary control group (C, $\mathrm{n}=8)$; sedentary control with 0.2 c.c. $\mathrm{AC}$ supplementation $(\mathrm{kg} /$ wt/day) (A, n=8); exhaustive exercise $(E, n=8)$; exhaustive exercise with 0.2 c.c. AC supplementation (kg/wt/day) (AE, $\mathrm{n}=8$ ). AC supplementation for two weeks. The experiment was approved by the Institutional Animal Care and Usage Committee of the Yuanpei University of Science and Technology and followed the guidelines established by the National Laboratory Animal Breeding and Research Center in Taiwan.

\section{Exercise Protocol}

Rats in groups $\mathrm{E}$ and $\mathrm{AE}$ were introduced to treadmill running with $15-20 \mathrm{~min}$ exercise bouts at 15 $30 \mathrm{~m} / \mathrm{min}$ for $6 \mathrm{~d}$ to accustom them to running by a modification of the method of Ji et al. (1991). The treadmill was equipped with an electric shocking grid on the rear barrier to provide the animal with exercise motivation (T510E treadmill device; DR instrument, Taipei, Taiwan). On the day of the exercise test, they were required to run to exhaustion on a five-lane inclined $\left(10^{\circ}\right)$ treadmill at a final speed of $30 \mathrm{~m} / \mathrm{min}$, which was approximately $70-75 \%$ of $\mathrm{VO}_{2} \max$ (Brooks \& White, 1978). The measurement of maximal $\mathrm{O}_{2}$ consumption $(100 \%$ $\mathrm{V} \mathrm{O}_{2} \max$ ) was considered valid only if the animal ran until it could no longer maintain pace with the treadmill (Somani et al., 1995). Therefore, exhaustion was determined as the rat being unable to upright itself when placed on its back. To eliminate diurnal effects, the experiments were performed at the same time $(09.00$ hours to 12.00 hours). 


\section{Sample Preparation}

The rats in the $\mathrm{C}$ and $\mathrm{A}$ groups were anaesthetized with ethyl ether and killed after $12 \mathrm{~h}$ fasting without exercise. Then, the rats in the exercise groups were killed immediately after exhaustive exercise. Heparinised blood samples were collected from the abdominal aorta. Blood samples were centrifuged at $1400 \mathrm{~g}$ at $4^{\circ} \mathrm{C}$ for $10 \mathrm{~min}$. The supernatant fractions (plasma) were used for the determination of plasma parameters.

\section{Plasma Parameters}

Plasma was used for the determination of lactate dehydrogenase $(\mathrm{LDH})$, creatine kinase $(\mathrm{CK})$, creatinine, glucose, and uric acid with an automatic analyzer (Hitachi 7170; Hitachi Ltd.).

Table 1. Exhaustive Exercise Time (min).

\begin{tabular}{lcc}
\hline groups & Mean & SD \\
\hline E & 67.77 & 9.22 \\
AE & $78.79 *$ & 9.09 \\
\hline
\end{tabular}

E, exercise group; $\mathrm{AE}$, exercise $+\mathrm{AC}$ supplementation group.

*: Mean values were significantly different between two groups

Table 2. Blood Parameters (mean \pm SD).

\begin{tabular}{lllll}
\hline & Group C & Group E & Group A & Group AE \\
\hline CK(U/l) & $358.98 \pm 125.53^{\mathrm{a}}$ & $1227.40 \pm 553.24^{\mathrm{b}}$ & $610.49 \pm 443.17^{\mathrm{a}}$ & $774.13 \pm 203.38^{\mathrm{a}}$ \\
$\mathrm{LDH}(\mathrm{U} / \mathrm{l})$ & $956.89 \pm 597.13^{\mathrm{a}}$ & $2108.32 \pm 513.99^{\mathrm{b}}$ & $1265.44 \pm 998.91^{\mathrm{a}}$ & $1300.93 \pm 513.99^{\mathrm{a}}$ \\
glucose $(\mathrm{mg} / \mathrm{dl})$ & $209.63 \pm 69.13^{\mathrm{a}}$ & $133.88 \pm 61.84^{\mathrm{b}}$ & $234.63 \pm 109.60^{\mathrm{a}}$ & $188.88 \pm 60.32^{\mathrm{a}}$ \\
uric acid(mg/dl) & $3.98 \pm 2.33^{\mathrm{a}}$ & $4.41 \pm 0.69^{\mathrm{a}}$ & $4.11 \pm 1.78^{\mathrm{a}}$ & $3.30 \pm 1.42^{\mathrm{b}}$ \\
creatinine $(\mathrm{mg} / \mathrm{dl})$ & $0.5 \pm 0.15^{\mathrm{a}}$ & $0.76 \pm 0.19^{\mathrm{b}}$ & $0.53 \pm 0.09^{\mathrm{a}}$ & $0.5 \pm 0.05^{\mathrm{a}}$
\end{tabular}

$\mathrm{C}$, control group; $\mathrm{E}$, exercise group; $\mathrm{A}, \mathrm{AC}$ supplementation group; $\mathrm{AE}$, exercise+AC supplementation group.

a b Mean values within a row with unlike superscript letters were significantly different $(\mathrm{p}<0.05)$. 


\section{LDH Activity}

The activities of LDH significantly increased in exercised rats $(2108.32 \pm 513.99$ U/I) compared with control rats $(956.89 \pm 597.13 \mathrm{U} / \mathrm{I})$. The increased activities of LDH in exercised rats were significantly decreased in exercised rats supplemented with AC $(1300.93 \pm 513.99$ U/I) (Table 2).

\section{Glucose}

The glucose in the plasma significantly decreased in exercised rats $(133.88 \pm 61.84 \mathrm{mg} / \mathrm{dl})$ compared with $\mathrm{C}$ rats $(209.63 \pm 69.13 \mathrm{mg} / \mathrm{dl})$. The glucose concentration was significantly increased in AE group $(188.88 \pm 60.32 \mathrm{mg} / \mathrm{dl})$ compared with E group $(133.88 \pm 61.84 \mathrm{mg} / \mathrm{dl})$ (Table 2).

\section{Uric Acid}

The uric acid concentration was significantly decreased in AE group $(3.30 \pm 1.42 \mathrm{mg} / \mathrm{dl})$ compared with E group $(4.41 \pm 0.69 \mathrm{mg} / \mathrm{dl})$ (Table 2).

\section{Creatinine}

The blood creatinine concentration significantly increased in exercised rats $(0.76 \pm 0.19 \mathrm{mg} / \mathrm{dl})$ compared with control rats $(0.5 \pm 0.15 \mathrm{mg} / \mathrm{dl})$. The increased creatinine concentration in exercised rats were significantly decreased in exercised rats supplemented with AC $(0.5 \pm 0.05 \mathrm{mg} / \mathrm{dl})$ (Table 2).

\section{Discussion}

The laboratory rat is a commonly used model for the evaluation of exhaustive exercise effects on biochemical changes in man. The present study aimed to examine $\mathrm{AC}$ supplementation in relation on exhaustive exercise induced fatigue in a rat model. In the present research, the mean exhaustive exercise time of treadmill running in group $\mathrm{AE}$ was significantly increase from group $\mathrm{E}$ (Table 1). It indicated that $\mathrm{AC}$ supplementation could increase exhaustive time.

In animal experiments, many researchers have already reported that exhauseive exercise elevates CK activity, $\mathrm{LDH}$, uric acid and creatinine in blood (Itoh et al., 2000; Jimenez et al., 2001; Marquez et al., 2001; Zajac et al., 2001). In the present study, compared with group $\mathrm{C}$, the plasma $\mathrm{CK}$ activity of group $\mathrm{E}$ was significantly increased about 3-fold (Table 2), and the LDH activity in the plasma was also significantly raised 2-fold respectively (Table 2). Inversely, the blood glucose content was significantly reduced in group $\mathrm{E}$ (Table 2). The exhaustive exercise caused oxidation damage, increasing $\mathrm{CK}$ activity significantly in the plasma. The CK marker is used to determine muscle damage.

Although most studies indicate that muscle injury is assessed through prolonged endurance exercise, it is obvious that it can be caused during high intensity shortterm exercise as well (Byrd, 1992; Friden \& Lieber, 1992). During running exercise, the extensor muscle of the lower limb performed eccentric actions as the foot touches the ground and the dorsiflexors of the ankle contract eccentrically. In eccentric exercise, the contracting muscle is forcibly lengthened as it develops tension, potentially causing damage. Therefore, endurance exercise, such as an exhaustive running exercise can induce damage and pathological alteration in skeletal muscle (Hsu et al., 2005). With high intensity exercise, the high force contractions cause muscle cell injury early in the exercise period (Friden \& Lieber, 1992).

Mair et al. (1995), demonstrated a transient rise in the serum concentrations of muscle proteins such as $\mathrm{CK}$, an indicator of muscle damage due to sarcolemma disruption, which cause a leakage of $\mathrm{CK}$ into the blood. In this study, the total CK activity significantly increased during exhaustive running exercise. We assign this to plasma CK increasing due to exercise-induced skeletal muscle damage. Intense exercise may increase the production of free radicals or reactive oxygen species. A free radicals prefers to steal electrons from the lipid membrane of a cell, initiating a free radical attack on the cell known as lipid peroxidation. Kanter et al. (1988), have demonstrated the post-exercise plasma CK elevations may be related to an exercise-induced lipid peroxidations. The AC is effective antioxidant, free radical scavenging activity, and inhibiting lipid peroxidation (Hseu et al., 2002).

The LDH activity levels rise as intensity increases during exercise. In our research, the $\mathrm{AC}$ supplementation significantly decreased LDH activity in plasma. The lower blood lactate concentration during running exercise presumably reflects a lower intramuscular lactate concentration and an increased relative contribution of anaerobic metabolism to ATP production. 
AC supplementation is a kind of antioxidant. In our research, the supplement of AC significantly decreased $\mathrm{CK}$ and $\mathrm{LDH}$ activity in plasma. These results showed that a supplement of AC efficiently inhibits fatigue induced by exhaustive exercise.

\section{Conclusion}

In conclusion, AC supplementation reduced the leakage of $\mathrm{CK}$ from skeletal sarcoplasma into blood streaming during an exhaustive exercise, and enhance work capacity. The reduction of plasma $\mathrm{CK}$ level may be due to $\mathrm{AC}$ that is effective for decrease of skeletal muscle cell membrance damage induced by exercise during the high intensity treadmill run. It still needs further investigation and pathological observation in a future study, including heart, live, kidney or muscle.

\section{Acknowledgments}

The authors would like to thank the Golden Biotechnology Corp., for financially supporting this research.

\section{References}

Brooks, G. A., \& White, T. P. (1978). Determination of metabolic and heart rate responses of rats to treadmill exercise. Journal of Applied Physiology, 45, 1009-1015.

Byrd, S. K. (1992). Alterations in the sarcoplasmic reticulum: a possible link to exercise-induced muscle damage. Medicine and Science in Sports and Exercise, 24, 531-536.

Chen, C. C., Shiao, Y. J., Lin, R. D., Shao, Y. Y., Lai, M. N., \& Lin, C. C. (2006). Neuroprotective diterpenes from the fruiting body of Antrodia camphorate. Journal of Natural Products, 69, 689-691.

Friden, J., \& Lieber, R. L. (1992). Structural and mechanical basis of exercise-induced muscle injury. Medicine and Science in Sports and Exercise, 24, 521-530.
Hseu, Y. C., Chang, W. C., Hseu, Y. T., Lee, C. Y., Yech, Y. J., \& Chen, P. C. (2002). Protection of oxidative damage by aqueous extract from Antrodia camphorate mycelia in normal human erythroctes. Life Science, $71,469-482$.

Hsu, C. C., Ho, M. C., Lin, L. C., Su, B., \& Hsu, M. C. (2005). American ginseng supplementation attenuates creatine kinase level induced by submaximal exercise in human beings. World Journal of Gastroenterol, $11(34)$, 5327-5331.

Itoh, H., Ohkuwa, T., Yamazaki, Y., Shimoda, T., Wakayama, A., Tamura, S., Yamamoto, T., Sato, Y., \& Miyamura, M. (2000). Vitamin E supplementation attenuates leakage of enzymes following 6 successive days of running training. International Journal of Sports Medicine, 21, 369-374.

Ji, L. L., Dillon, D., \& Wu, E. (1991). Myocardial aging: antioxidant enzyme systems and related biochemical properties. The American Journal of Physiology, 261, R386-R392.

Jimenez, L., Lefevre, G., Richard, R., Couderc, R., Saint George, M., Duvallet, A., \& Rieu, M. (2001). Oxidative stress in hemodialyzed patients during exhausting exercise. The Journal of Sports Medicine and Physical Fitness, 41, 513-520.

Kanter, M. M., Lesmes, G. R., Kaminsky, L. A., La Ham-Saeger, J., \& Nequin, N. D. (1988). Serum creatine kinase and lactate dehydrogenase changes following an eighty kilometer race. Relationship to lipid peroxidation. European Journal of Applied Physiology and Occupational Physiology, 57, 60-63.

Lawrence, M. E., \& Kirby, D. F. (2002). Nutrition and sports supplements: fact or fiction. Journal of Clinical Gastroenterology, 35, 299-306.

Lee, I. H., Huang, R. L., Chen, C. T., Chen, H. C., Hsu, W. C., \& Lu, M. K. (2002). Antrodia camphorate polysaccharides exhibit anti-hepatitis B virus effects. FEMS Microbiology Letters, 209, 63-67. 
Liu, J. J., Huang, T. S., Hsu, M. L., Chen, C. C., Lin, W. S., \& Lu, F. J. (2004). Antitumor effects of the partially purified polysaccharides from Antrodia camphorate and the mechanism of its action. Toxicology and Applied Pharmacology, 201, 186-193.

Mair, J., Mayr, M., Muller, E., Koller, A., Haid, C., Artner-Dworzak, E., Calzolari, C., Larue, C., \& Puschendorf, B. (1995). Rapid adaptation to eccentric exercise-induced muscle damage. International Journal of Sports Medicine, 16, 352-356.

Marquez, R., Santangelo, G., Sastre, J., Goldschmidt, P., Luyckx, J., Pallardo, F. V., \& Vina, J. (2001). Cyanoside chloride and chromocarbe diethylamine are more effective than vitamin $\mathrm{C}$ against exerciseinduced oxidative stress. Pharmacology \& Toxicology, 89 , 255-258.

Maughan, R. J., King, D. S., \& Lea, T. (2004). Dietary supplements. Journal of Sports Science, 22, 95-113.

Shen, Y. C., Chou, C. J., Wang, Y. H., Chen, C. F., Chou, Y. C., \& Lu, M. K. (2004). Anti-inflammatory activity of the extracts from mycelia of Antrodia camphorate cultured with water-soluble fractions from five different Cinnamomum species. FEMS Microbiology Letters, 231, 137-143.
Somani, S. M., Frank, S., \& Rybak, L. P. (1995). Responses of antioxidant system to acute and trained exercise in rat heart subcellular fractions. Pharmacology, Biochemistry, and Behavior, 51, 627634.

Wang, G. J., Tseng, H. W., Chou, C. J., Tsai, T. H., Chen, C. T., \& Lu, M. K. (2003). The vasorelaxation of Antrodia camphorate mycelia: involvement of endothelial Ca2+-NO-cGMP pathway. Life Science, 73, 2769-2783.

Wu, S. H., Ryvarden, L., \& Chang, T. T. (1997). Antrodia camphorate ("niu-chang-chih"), new combination of a medicinal fungus in Taiwan. Botanical Bulletin of Academia Sinica, 38, 273-275.

Zajac, A., Waskiewicz, Z., \& Pilis, W. (2001). Anaerobic power, creatine kinase activity, lactate concentration, and acid-base equilibrium changes following bouts of exhaustive strength exercises. Journal of Strength and Conditioning Research, 15, 357-361.

\section{Correspondence:}

Pu-Hsi Tsai

Mailing address: No. 306, Yuanpei street,

Hsin Chu, Taiwan.

Tel: +886-3-5381183 ext 8380

Fax: +886-3-6102374

E-mail: bush@mail.ypu.edu.tw 